\title{
An Ethical Analysis of the Supply Chain Management in China
}

\author{
DeguiZhu \\ Institute for Business and Economic Research \\ Harbin University of Commerce \\ Harbin, China \\ Zhudegui2004@163.com
}

\author{
Liqiongyu Zhu \\ Institute for Business and Economic Research \\ Harbin University of Commerce \\ Harbin, China \\ zhuliqiongyu@hotmail.com
}

\begin{abstract}
This paper argues that we should establish a set of rules and credit management system to enforce the rigid discipline of moral rules. We also should create a fair and sound environment of market competition for supply chain enterprises. On the other hand, the self-regulatory mechanism of market players should be improved to strengthen the role of the merchant guild, industry associations and various types of market organization. This paper also points out that the ethical standards which are deemed to be the code of enterprises' conduct need to be established to accommodate the market economy. The core enterprises in an ethical management play an exemplary role. Simultaneously we should establish a code of ethics to regulate the stakeholders such as customers, suppliers, competitors and governments. The ethical decision-making process must be constructed. In addition to the economic, technical analysis in the decision-making, the supply chain enterprises should conduct an ethical analysis on correcting the misdeeds of corporate decision-making. At last, we should take measures to educate employees with moral standards in the inside of the supply chain enterprises.
\end{abstract}

\section{Keywords-ethic;s management; supply chain; China}

\section{INTRODUCTION}

A decade ago the concept of supply chain management just occurred in Chinese mass media. There is a convergence in the theoretical understanding of the sector for the logistics and supply chain among scholars, but in practice, the successful enterprises are a handful, most of the logistic organizations are not in place, not to mention the ethics of the supply chain. Theoretical research and application of supply chain management are in its infancy, there are still many problems, such as technical issues, the standardization issues, the question of perception, organizational structure, trading partners and logistics costs, information sharing issues [1]. In reality, the supply chain management goals are not easy to reach. Because every enterprise is an independent economic entity, their particular interests are still clung to, in the supply chain after adding the supply chain. The "interest paradox" is very prominent, which leads directly to the low trust and noncooperation of the enterprises in the supply chain. At the same time, because of the worry of possible disclosure of commercial secrets, there are few enterprises that can make the partners information disclosed including the information of their research, manufacturing technology, production and sales data. These are a hindrance to carrying out the supply chain management of "joint planning, information sharing" concept. In the supply chain, each enterprise is equal, but powerful enterprises have the bargaining power to possess the advantages of power objectively. Thus those who have more power should bear more responsibility in the process of establishment and maintenance of the supply chain, this will be an important problem to be solved in practice. Another problem for Chinese enterprises at present is that many enterprises are at the end of the international industrial chain due to their lower productivity. Some ethical requirements of the evaluation and certification standards are becoming the threshold to acquire admittance to international supply chain. And from the economic point of view, it is not conducive to control the cost for the domestic enterprises, so how supply chain enterprises can survive and develop among the international competition is also the urgent problems. These problems are directly related with the supply chain management with the intrinsic ethical characteristics.

At present, a large number of the domestic research literature on supply chain are mostly from the angle of economic and the management science, using the game model and other tools of economics to explain their views. They mainly focused on how to choose partners, and how to set up trust relationship among supply chain enterprises. In the abroad, the literature of supply chain management is rich, especially in Japan and the United States of America, which research of supply chain in the world represents leading level. They are very concerned about the ability of information processing and information sharing, and they also emphasize the cooperation between the supplier and the retailer in each node of supply chain so as to improve the material flow, cash flow, information flow.

This paper embarks from the visual angle of economy ethics, using some important concepts in economic ethics to analyze the characteristics of ethics of supply chain management, and exploring the use of ethical norms in supply chain management. This paper also points out that the specific responsibilities of supply chain and its member enterprises are how to assume these responsibilities with a view of new theories of the supply chain management. And supply chain management may be improved in practice with the important role in the ethical and moral norms in economic activities elaborated. In the context of the current global competition, the Chinese enterprises participate in the supply chain management 
to exploit the international markets with the transformation of the enterprise competition to the supply chain competition, so its competition is the all-round including not only capitals, technology, talents and new management concepts, but also the cultural and ethical factors. Ethics assume an increasingly important task in the supply chain management of china at present.

\section{THE ETHICAL CAUSES OF THE PLIGHT OF THE SUPPLY CHAIN MANAGEMENT}

Because of the low level of trust among enterprises, it is difficult for us to form a long-term close cooperation and information sharing, and ignoring a range of issues involved in the international supply chain must cross the moral threshold which indicates that the Chinese enterprises in the implementation of supply chain will face the ethical dilemmas.

\section{A. The Trust of Family Doctrine}

In China, A person doesn't cultivate relationships and networks entirely in the genetic relationship, then he will not be fully trusted. In traditional Chinese society, people usually do have a sense of responsibility or obligation for blood relatives. Extreme doctrine of the family, the lack of the male heritage and the distrust of whom are neither relative nor friend combine the traditional mode of economic behavior in China. In the Chinese community, the basic small family management consists in small-scale enterprises. Chinese enterprises face difficulties in the shift from family management to professional management, it is associated with that Chinese are strongly inclined to trust only the biologically related, rather than to trust outside the family. Even those who profess "justice", "gentlemen's love of money in a proper way" often work on their own in the market, rarely trust those outside of the family. A lack of trust relationship is very difficult for them to form associations, organizations and economic enterprises, let alone the supply chain with close co-operation [2].

\section{B. The New System of Values and Ethics under Formation in China}

The fundamental changes have taken place in China's socio-economic structure, social and spiritual areas of life since the policy of reform and opening up was implemented. Such dramatic changes are accompanied by the transmutation of traditional morality and anomie with the lack of a new unified value criteria, people don't know how to behave and think. The Chinese traditional morality has been questioned and criticized. We face the strong impact of the commodity economy, having no time to remodel moral system from both the old and the new economic system [3]. It is possible to generate and resurrect some of the decadent ideas and behavior. For instance, that the commodity producers who are independent and of encouragement and self-identity are absolutized will lead to extreme individualism; That the equivalent exchange principles and the principle of seeking profits are absolutized will lead to money worship and acts of unfair competition; And that the emphasis on personal interests is absolutized will lead people to chasing fame, fortune and hedonism, and so on. These confused thinking and decadent values don't fit the ethics of the supply chain.

\section{The Chinese enterprises moral reconstruction in a predicament}

In the 1920s and 1930s, a large number of intellectuals with more radical thinking introduced a large number of modern Western culture and philosophical thoughts, such as postmodernism, deconstruction thoughts. All those which implied moral relativism or non-moralism were magnified or intentionally distorted eroded the ethical basis of mainstream ideology, and some economists preached non-ethical "science" to cater to the desires of many people chasing wealth. The tide of market economy often makes our business disoriented, in reality, the brutal competition in the market, especially when our legal system is not well established the enterprises tried to survive, non-ethical "economics" is "nonsense" in the eyes of some people [4]. Therefore, although the benefits of supply chain management have been known in theory, we really want a transition in practice, and there are many obstacles. Chinese enterprises need to solve the following problems including the outsourcing of the business, allowing other companies to participate in decision-making or management of the enterprise, and keeping pace with other enterprises. Even companies like Haier, in the process of implementation of supply chain management also encountered a lot of difficulties. The members of the supply chain are not only of fair potent contract, but also of the overall best concept. They also need to trust the moral force to ensure the accessibility of the implementation of supply chain management.

\section{Lack of People-oriented in the Supply Chain Management}

The people of the ethics requires companies to be peopleoriented, respect for employees, staff development, recognition of the difference varies from person to person, capabilities, and people make the best material. Not only respect for the employees within the organization, but also extended to the respect of other stakeholders. In the current of the supply chain enterprises, especially most of the logistics enterprises do not respect the staff are quite serious disregard for human dignity, rights and value. The question of perception [5]. Managers and employees within most enterprises lack of awareness of the importance of ethical management in the management decision to focus only on the analysis of the economic and legal aspects, neglecting or ignoring the ethical analysis.

\section{THE ETHICAL MEASURES OF IMPROVING THE SUPPLY CHAIN OF MANAGEMENT}

For the status quo of supply chain management in China, when we are speeding up the popularization and application of bar code and e-commerce, accelerate the construction of commodity information database and distribution centers, and develop the third-party logistics supply chain, the ethical factors playing an important role in this regard should also be improved.

\section{A. Improve the Business Credit Files}

With the social credit system construction, improving enterprise credit files are necessary. In fact, this is one aspect of the construction of corporate culture, including the Journal of the enterprises as well as websites, which focus on the 
aspects of corporate moral responsibility. These measures not only enhance the corporate image among the public, but also facilitate the partner to query information to avoid adverse selection caused by asymmetric information. If this information log files commonly practice in society, the selection of partners of the supply chain in the beginning of the formation can easily examine the full range of candidate enterprises. The enterprises make money in the long run, relying on moral consideration for the behavior of the shortterm interests, the moral image for the economic activities of enterprises has more important; From the domestic point of view, the survival of the labor, working conditions are also concerned to improve labor welfare, the devotion in this area is necessary; From the international trend, the market shares are getting smaller and smaller, so the enterprises actively assume moral responsibility. Because economic efficiency is directly linked to economic globalization trend all corners of the world.

\section{B. Injection into the Economy Ethics in the Decision-making Process and Strengthening Cooperation}

Entrepreneurial training has increasingly become the subject of concern, but modern enterprise awareness and training effectiveness have serious problems. We should increase some interpretation on the international certification standard curriculum. This is the requirements of the enterprises to enhance their international competitiveness. With the promotion of SA8000 basic knowledge, the enterprises can strengthen the cohesion. To strengthen contacts and exchanges between the partners, especially in the supply chain core business, learning from Wal-Mart's practice, the enterprises can supervise and guide the suppliers. Our enterprises also have the responsibility to implement advanced operating methods, helping foster mutual trust in the supply chain.

\section{Emphasis on Reverse Logistics Management and the Integrity of the Supply Chain}

In each node, enterprises have a responsibility to ensure the safety, once the products cause any harm to consumers, enterprises have a responsibility to recover timely, effectively and safely. To build the integrity of the supply chain, we need the implementation of the supply chain with green and social responsibility. Supply chain management focuses on the perspective of broader efficiency, all members trust each other, take risks, and share revenue. The overall best interests of companies and trust relationship is based on the nature of requirements. How to create a successful supply chain is an ethical issue, and within the supply chain management, supply chain is inseparable from the construction of ethics. Fostering trust is a pressing matter of the moment, but the cultivation of the trust is not only attributed to enterprises, at present China should focus on attention of the people and improving legal system. Since laws and regulations are not perfect and not strictly implemented, this is the important cause of the trust crisis [6]. The laws and regulations of our country developed from the original planned economy, and changes in the market situation is becoming more and more complex, so there are many loopholes, which are increasingly unable to meet the needs of the development of cooperative relations between enterprises.

\section{Improving the Selection Criteria for Partners}

Chinese enterprises should learn from the successful experience of the foreign supply chain, looking for partners with no-battling in pricing. Since the socialist market economy system is not perfect, the enterprises should look far ahead from a high point. Although the economic benefit is the basis of survival, it is definitely not the only. And some enterprises in our country are paying more attention to "morality" and good performance of the enterprises. In fact, in the ability of matching conditions, the enterprises have a good reputation and social responsibility, and the information can be queried by the social credit system to investigate the other previous cooperation with other enterprises history. The ability can also be improved like WAL-MART's concern about each other's working environment and production safety situation. It can maintain the entire supply chain in the mind of the public moral image to maximize customer value [7].

\section{E. Adapting to the Global Procurement Rules}

As a whole, Multi-National Corporations dominated China for the manufacturing base and the processing plant of the world, as a labor-intensive processing enterprises, the majority of domestic manufacturers are in the end of the international supply chain, so we must be clear about what the MultiNational Corporations in the global procurement focus on. Most domestic enterprises still think that the price is the only key, but when they once again raise the price in front banner, purchasers have repeatedly failed, and sometimes even the basic access threshold could not enter. Some relevant management with the implementation of new international standards has become the international market access threshold [8]. The most typical SA8000 certification standards which Chinese enterprises must pay close attention to should be actively adapted to early. The implementation of the relevant social responsibility, production safety and environmental protection force Chinese enterprises to look for their own reasons of the real development method under the environment of economic globalization. The industry realized that the market competition is fierce, we will increase the weight of a competition in terms of corporate social responsibility [9]. At the beginning of 2013, domestic media reported the European and American countries kept track of the developing countries including China Compulsory SA8000 certification promotion news, and many enterprises in this aspect has been positive action, SA8000 even more effective than "labor law". Some reports suggest that the wages of the factory workers in the southern coastal areas were improved and enhanced.

In short, trust has its unique role in the supply chain. People may only consider their own interests, but the enterprises should trust each other in the process of cooperation, and jointly cope with emergencies. Gradually they can establish the expectations and trust in good faith with each other. The trust of supply chain alliance refers that other members of the enterprise don't take advantage of his weakness in the transaction, and they believe that the partnership will help them care for their welfare. 


\section{ACKNOWLEDGMENT}

This paper is supported by the national philosophy and Social Science Fund. (13CJL006).

\section{REFERENCES}

[1] Gold, Stefan, Stefan Seuring, and Philip Beske, "Sustainable supply chain management and inter - organizational resources: a literature review," Corporate Social Responsibility and Environmental Management, Vol.17.4,2010,pp. 230-245.

[2] Roberts, Sarah, "Supply chain specific? Understanding the patchy success of ethical sourcing initiatives," Journal of Business Ethics, Vol. 44.2-3,2003,pp.159-170.

[3] Collinson, Chris, "The Business Costs of Ethical Supply Chain Management: Kenya Flower Industry Case Study," Natural Resources Institute (NRI) ,2001,pp321-331.

[4] Maloni, Michael J., and Michael E. Brown, "Corporate social responsibility in the supply chain: an application in the food industry," Journal of business ethics, Vol. 68.1,2006,pp.35-52.

[5] Ellram, Lisa M, "Supply-chain management: the industrial organisation perspective," International Journal of Physical Distribution \& Logistics Management,Vol. 21.1,1991,pp.13-22.

[6] DeLaurentis, Teresa, "Ethical Supply Chain Management," China Business Review,Vol. 36.3,2009,pp.38-41.

[7] Jamison, Louise, and Hilary Murdoch. Taking the temperature: ethical supply chain management. Institute of Business Ethics, 2004.

[8] Cousins, Paul D., et al, "Creating supply chain relational capital: the impact of formal and informal socialization processes," Journal of Operations Management,Vol.24.6,2006,pp.851-863.

[9] Carter, Craig R., and P. Liane Easton, "Sustainable supply chain management: evolution and future directions," International Journal of Physical Distribution \& Logistics Management, Vol. 41.1,2011,pp.46-62. 